\title{
Collective Bargaining for University Faculty: A Legal Perspective
}

\author{
D. D. CARTER*
}

Present signs indicate that university faculty are moving slowly, but inexorably, along the road to collective bargaining. Faculty in Quebec appear to be in the vanguard of this movement, but there are signs that faculty in other provinces are following in the same direction. To many, this may be an alarming development, giving rise to a number of fears, such as union organizers disrupting collegial relationships; a closed shop being imposed upon the university community; a highly formalized employment relationship replacing the traditional university-faculty relationship; union solidarity replacing academic excellence; the strike and picket line replacing rational discussion; and government and union interference in the administration of the universities. Such developments would indeed be undesirable, but I submit that they do not necessarily flow from collective bargaining and the present legal structure established to regulate it.

To support this statement, it is necessary to describe the more significant features of the existing legal structure regulating collective bargaining. This structure is characterized by 1) positive legal support to encourage employees to organize into collectives with the purpose of providing a countervailing force to match the economic power of the employer; 2) strict limits on the use of economic sanctions by either employees or employers; and

3) a reluctance to interfere in those situations where employers and employees are able to establish a harmonious collective bargaining relationship. Since each of these features plays a key role in shaping our collective bargaining system, further explanation is needed.

A primary purpose of existing collective bargaining legislation is to encourage the organization of employees into collectives for the purpose of bargaining with employers. One method of legal assistance is for labour relations legislation to prohibit certain types of employer conduct, including employer statements, that interfere with employee organizations. Perhaps of even greater assistance to trade unions is the status conferred by law where the union has organized a majority of employees in a particular constituency, called the bargaining unit. This status, acquired through a procedure called certification, gives the union exclusive authority to bargain for all employees in the bargaining unit, even though some of these employees may not be members of the union. The law supports this status by prohibiting the employer from bargaining with any other person or organization. The result is that the law gives a seat at the bargaining table to a union that becomes certified as bargaining agent, whether the employer likes it or not.

Bargaining status, however, does not carry with it the right to strike at all times. In fact, existing legislation strictly curtails the right to resort to economic sanctions. Labour legisla-

*Associate Professor, Faculty of Law, Queen's University. 
tion relating to the private sector only permits the strike and the lockout where the parties have made a full attempt to negotiate a collective agreement and have reached an impasse. Strikes for the purpose of obtaining employer recognition for a union or strikes for the purpose of resolving differences arising under a collective agreement are strictly prohibited. Labour relations legislation governing the public sector usually goes further in restricting the right to strike. In some Canadian jurisdictions, the right to strike has been totally proscribed, being replaced by the procedure of compulsory arbitration. ${ }^{1}$ In other jurisdictions, the right to strike is still available, but the alternative of compulsory arbitration is also made available. ${ }^{2}$ Finally, there are some jurisdictions where public servants are given the same right to strike as employees in the private sector, although public attitudes against public service strikes may in fact curtail the actual exercise of this legal right. ${ }^{3}$

Despite the fact that the law does play an active role in assisting employee organization and in curtailing resort to economic sanctions, it is still possible for a collective bargaining relationship to exist without recourse to the legal structure. For example, if an employer voluntarily recognizes a union and bargains with it, there is no need, or requirement, for the union to seek to have its role legitimized by the legal system. Furthermore, the law does not usually dictate the terms of a collective agreement negotiated by an employer and union. The exceptions are that the parties are required to agree not to resort to economic sanctions during the currency of the agreement, and the parties must provide some procedure for the final settlement of disputes arising under their collective agreement. On the other hand, if the parties can solve contractual grievances by negotiation, there is then no need to resort to final settlement procedures, usually grievance arbitration. Even if the parties find that they must resort to grievance arbitration, the law gives them the opportunity to select the arbitrator by agreement between themselves. Thus, the present legal structure provides ample scope for the parties to work out their differences without resort to the law.

In fact, it is even possible for collective bargaining to occur outside of labour relations legislation. A good example is the school teachers of Ontario, a group excluded from labour relations legislation, but who in fact now bargain collectively with school boards. Another group of employees that established a collective bargaining relationship outside of existing labour relation legislation was the Ontario Crown employees, although this relationship is now regulated by statute. A further example, close to home, is the rudimentary form of collective bargaining now engaged in by faculty at some Canadian universities.

Since it is possible to bargain collectively without recourse to the existing legal structure, it is possible to conclude that collective bargaining by university faculty need not be

${ }^{1}$ For example, the Ontario Crown Employees Collective Bargaining Act completely prohibits the strike and lock-out, substituting arbitration as the method of dispute resolution.

${ }^{2}$ The federal Public Service Staff Relations Act and the New Brunswick Public Service Labour Re. lations Act provide an option of compulsory arbitration or strike action. The right to strike is restricted to some extent by a provision in both Acts whereby certain "designated" employees, whose services are considered to be necessary "in the interest of the safety and security of the public," are prevented from striking.

${ }^{3}$ The collective bargaining laws of Quebec, Saskatchewan, and Manitoba make very little distinction between the private and public sectors. Recent experiences in Quebec, however, indicate that, as a practical matter, it is more difficult to exercise the right to strike in the public sector. 
shaped in the mould of the existing legal structure. If universities and members of faculty could agree on their own procedures for collective bargaining, then certain features of collective bargaining, considered to be incompatible with the university community, could be avoided. It would be possible, for example, to avoid purging faculty associations of colleagues with managerial responsibilities, a necessary exercise if faculty associations were to seek legal status. Universities and their faculty could also bargain for a set of rules to govern the employment relationship different than those bargained for in the industrial sector. ${ }^{4}$ These are only two examples, but the point is that the present legal structure does allow scope for the parties to build their own collective bargaining relationship through voluntary co-operation.

Once a collective bargaining structure is established, however, it may be increasingly difficult for faculty and universities to operate in a complete legal vacuum. Two factors make it likely that legal rules may be imposed from the outside. First, it is probably being overly optimistic to think that all matters in dispute between universities and faculty members can be resolved through co-operation. In cases of impasse, either side may be tempted to resort to the existing legal structure for assistance, or even attempt to obtain new legislation to govern their collective bargaining relationship. Even if the parties can resist the temptation to invoke the law for reasons of self-interest, it is quite possible that governments may decide that they have some interest in the collective bargaining process and attempt to regulate it by legislation. The government, after all, is now very much the paymaster of faculty, so that the effective exercise of collective power by faculty may well arouse their interest.

In view of the likelihood of some form of legal intervention, it is important to ask whether the present legal structure meets all the needs of university collective bargaining. At the present time, in Canada, there is a well-established legal regime for private sector collective bargaining, and an emerging legal regime for public sector collective bargaining. Although both structures possess many common elements, there appear to be two main differences between them. First, collective bargaining legislation dealing with the public sector usually places greater restriction on the use of economic sanctions. A second difference is that the constituencies for collective bargaining, the bargaining units, are generally much larger in the public sector than in the private sector. This difference may well be due to the fact that public sector collective bargaining is much more of an exercise in political persuasion than is private sector bargaining.

The next question is which one of these two existing structures is more appropriate for university collective bargaining. My own view is that the public sector regime is the more suitable of the two, although by no means completely appropriate. Some general considerations support this opinion. First, universities now appear to be much more closely related to the public domain than to private enterprise. The fact is that governments are now the primary source of financing for our universities, making the operation

${ }^{4}$ The question of the compatibility of collective bargaining and a merit system for the determination of salaries was touched upon in a recent arbitration award (October 29, 1973) involving the Board of Governors of Ryerson Poly-technical Institute and the Ryerson Faculty Association. The arbitrator, Mr. H. D. Brown, although refusing to award the merit system requested by the employer and opposed by the faculty association, did indicate that a merit system could fit within a collective bargaining framework, if agreed to by both parties. 
of universities a matter of public concern. A further consideration is that the value of the type of service provided by the university, like many of the services provided by departments of government, cannot be readily determined by market-place considerations. The question of how much these services are worth is more a political decision to be made by government than one to be dictated by the market place, since the government effectively controls the market for such services. Moreover, it is difficult to apply market concepts such as productivity when dealing with the type of services provided by universities and governments. A third consideration is that there is a public expectation that university services, like other public services, should not be withheld. Certainly, if the services provided by the university were interrupted, it would be difficult to make up the loss. The resulting disruption to the teacher-student relationship would be difficult to repair, no matter how much extra effort was made after the strike. Although some of our students may disagree with this opinion, I believe that the services provided by the university are of an essential nature, which means that any interruption of them would likely be regarded with disfavour by the public. These general considerations have, therefore, led me to conclude that university collective bargaining is likely to be more akin to public sector collective bargaining.

This conclusion can be tested by applying the unique features of the public sector collective bargaining structure to university collective bargaining. As I have mentioned, the constituency for collective bargaining, the bargaining unit, takes a different shape than its private sector counterpart. The public sector bargaining unit is generally as wide, in geographic terms, as the unit of government with which the bargaining unit is dealing, and may or may not be defined along occupational lines. ${ }^{5}$ The result is that, in the public sector, bargaining units generally tend to be much larger and fewer in number. Given the greater restraints on the right to strike in the public sector, the larger bargaining unit is probably necessary for employees to be able to exercise influence at the bargaining table. Instead of the threat of economic sanctions, the government as employer is faced with the threat of disapproval by a significant block of voters, who may also be able to enlist the support of the general public in aid of their cause.

If the public sector model were applied to university collective bargaining, the result could be the establishment of large province-wide bargaining units, one for academic staff and one for non-academic staff, to deal with the government as paymaster. Although it might be more desirable for purposes of bargaining power to have just one large bargaining unit, I doubt whether this would occur. The fact is that there is probably not a sufficient community of interest among academic and non-academic staff to make such a large bargaining unit sufficiently cohesive. Moreover, a number of unions now have established claims to represent the non-academic staff and it is doubtful, in view of the uncertainty of organizing academic staff, whether these unions will give up their claims for a chance to organize one large bargaining unit.

On the other hand, if the private sector model were applied, the result might well be

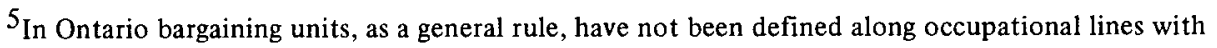
the result that there are only four bargaining units (with one unit much larger than the other three) covering most employees of the province. In the federal public service, on the other hand, bargaining units have been defined along occupational lines and the result has been substantially more bargaining units than in Ontario. 
a number of local bargaining units at each university. Non-academic staff might form a number of units at each university, and it is possible that academic staff, too, might form a number of units at each university. Once organized, these units would then bargain with their respective universities. The result is likely to be unsatisfactory. The fact is that the university is not the real paymaster, so that collective bargaining efforts would probably be misdirected. Even if the bargaining units were to attempt to apply some pressure on government, it is doubtful whether their efforts would have any significant impact. Thus, the public sector approach of large bargaining units dealing with government appears to be more appropriate than the fragmented approach of the private sector model.

The method of dispute resolution provided by the public sector model, compulsory arbitration, also appears more suitable to faculty collective bargaining. The strike does not appear to be an effective method of resolving disputes arising out of faculty collective bargaining. First, because of the superior economic position of the paymaster (government), the most that strike action would hope to achieve is that public attention be brought to bear on the dispute. It is doubtful, however, whether public reaction would be favourable to a faculty strike, especially if university services are regarded as being essential. Second, and perhaps more important, is the fact that most faculty would likely be very loath to withdraw their services. Not only would such a withdrawal of services disrupt the student-teacher relationship but, to many, it would also represent a retreat from reason. Finally, faculty may well do better under arbitration, since the professional arbitrator may well be sympathetic to the plight of fellow professionals. 6 Thus, I would suggest that, if an impasse developed, most faculty would prefer to have the choice of compulsory arbitration to resolve the impasse.

The public sector collective bargaining model does appear to be more suitable for university collective bargaining, but I would not wish to see that structure applied to the universities without modification. If universities are to retain any of their traditional autonomy from government, it is necessary that the government not be allowed to assume the full role of employer at the bargaining table. The problem, as I see it, is that the government in its role as paymaster must be present at negotiations, since collective bargaining would probably be meaningless without its presence. On the other hand, if the government is present at the bargaining table, it may insist on playing the role of employer as well as the role of paymaster. The result could be a serious erosion of university autonomy.

There are two methods that might be used to overcome this problem. First, some attempt could be made to restrict the issues on the bargaining table. Perhaps a distinction might be made between issues relating to the terms of employment of faculty and issues relating to the management of the universities. I would suggest, however, that such a distinction would be difficult to maintain, since issues have a tendency to overlap. It would be difficult, for example, to bargain for wages without talking of class size. To

${ }^{6}$ In the recent Ryerson award, see footnote 4 , the arbitrator awarded a general increase of $7 \frac{1}{2} \%$ in addition to any annual increment to which faculty would be entitled under the incremental system. In making this award, the arbitrator recognized the effect of both inflation and the growth of the gross national product, expressly stating that persons in educational professions were entitled to a share in any growth of the economy. 
give another example, the question of tenure relates both to terms of employment and to the management of the university. Moreover, faculty demand for greater participation in the running of the university may well be one of the reasons for its adoption of collective bargaining. If this is the case, then faculty may be reluctant to see issues relating to the management of the university considered as non-bargainable. ${ }^{7}$ Governments, as well, may not wish to see issues restricted in this way, when they are going to be paying most of the cost of the wage increases resulting from collective bargaining. Thus, I would suggest that any attempt to limit the range of bargainable issues in advance of bargaining is likely to create problems at the bargaining table.

The second method of protecting university autonomy during the collective bargaining process would be to provide for a strong university presence at the bargaining table. By this I mean that those that manage the university, as well as the bargaining agent and the government, should be present at the bargaining table. Even more desirable would be a system that provided for the universities and faculties working out their differences before the bargaining session with government. This might be accomplished by a two-tier system of collective bargaining, consisting of a lower tier at which university and faculty worked out their differences between themselves, and an upper tier where a common front of university and faculty bargain with government. This type of system, which now appears to be established in Britain, might be workable in Canada. ${ }^{8}$ The university and its faculty probably do have many interests in common, so that agreement at the lower tier may not be that difficult to achieve. Moreover, the need for a strong common front with which to meet government will provide an important incentive for agreement at the lower level. At the higher level, the common front of university and faculty bargaining agent may well provide a sufficiently strong voice to protect university autonomy from government encroachment and at the same time, bargain for a salary scale and a salary budget. The success of this bargaining procedure would, of course, very much depend on how persuasive the university common front is in making its argument to the government and the general public.

At first glance this form of collective bargaining may not appear to be much different from the present appeals by universities for government funds. There are, however, two important differences. First, there would be greater participation by faculty in the process of dealing with government. Second, the government would be made directly accountable for the salaries of university faculty. This is in contrast with the present system where governments, by simply setting general guidelines for financing, obscure their role as paymaster of faculty salaries.

In conclusion, I would suggest that all members of the university community should be giving serious thought to the possibilities of collective bargaining. Although faculty collective bargaining may never be a reality for universities, the university community

${ }^{7}$ This type of distinction has been a contentious issue with school teachers in Ontario. The recommendation of the Reville Report (The Report of the Committee of Inquiry into Negotiation Procedures Concerning Elementary and Secondary Schools of Ontario 1972) that such a distinction be established has met with sharp criticism from the teachers.

${ }^{8}$ This structure is examined in greater detail in B. L. Adell and D. D. Carter, Collective Bargaining for University Faculty in Canada (Kingston: Industrial Relations Centre, Queen's University 1972). 
should at least be giving consideration to this possibility. Some thought, moreover, should be given to the question of the appropriate structure for faculty collective bargaining. In devising this structure, care should be taken to borrow those features of the existing collective bargaining structures that are appropriate to the university. If this caution is kept in mind, then it may very well be possible to shape a collective bargaining structure that will be compatible with the traditional values of the university. 